Annu Rev Physiol. 2017 February 10; 79: 425-448. doi:10.1146/annurev-physiol-022516-034234.

\title{
Receptor-Mediated Endocytosis in the Proximal Tubule
}

\author{
Megan L. Eshbach and Ora A. Weisz \\ Renal-Electrolyte Division, University of Pittsburgh School of Medicine, Pittsburgh, Pennsylvania \\ 15261
}

\begin{abstract}
Cells lining the proximal tubule (PT) of the kidney are highly specialized for apical endocytosis of filtered proteins and small bioactive molecules from the glomerular ultrafiltrate to maintain essentially protein-free urine. Compromise of this pathway results in low molecular weight (LMW) proteinuria that can progress to end-stage kidney disease. This review describes our current understanding of the endocytic pathway and the multiligand receptors that mediate LMW protein uptake in PT cells, how these are regulated in response to physiologic cues, and the molecular basis of inherited diseases characterized by LMW proteinuria.
\end{abstract}

\section{Keywords}

apical; megalin; cubilin; kidney; albumin; proteinuria; cystinosis; Dent disease; Lowe syndrome

\section{INTRODUCTION}

Epithelial cells that form the proximal tubule (PT) play an essential role in the retrieval of ions and proteins that escape the glomerular filtration barrier. Cells in the proximal convoluted tubule (which includes the S1 and S2 segments) express high levels of the multiligand receptors megalin and cubilin, which mediate the efficient uptake of low molecular weight (LMW) proteins and other ligands from the filtrate. The apical endocytic pathway in PT cells is uniquely specialized to accommodate the high capacity needs of these cells and is acutely and chronically regulated in response to changes in ligand exposure. Yet despite the critical role of endocytosis in PT function, we know little about how the apical endocytic pathway is organized and regulated in these cells. Numerous genetic, acute, and chronic diseases impair the endocytic uptake of filtered ligands by PT cells, resulting in LMW proteinuria. Megalin and cubilin bind to numerous vitamin carrier proteins, and defective uptake of these proteins leads to vitamin deficiencies. In many instances, kidney function deteriorates progressively in patients with LMW proteinuria. However, it remains unclear whether LMW proteinuria is a marker of PT damage or a direct cause of further damage (1). A better understanding of the PT apical endocytic pathway and the consequences of its dysfunction may thus identify new interventional targets to prevent or limit kidney disease.

\section{DISCLOSURE STATEMENT}

The authors are not aware of any affiliations, memberships, funding, or financial holdings that might be perceived as affecting the objectivity of this review. 


\section{MULTILIGAND RECEPTORS OF THE PROXIMAL TUBULE}

The multiligand receptors megalin and cubilin coordinate the uptake of most filtered proteins and many other small bioactive molecules from the glomerular ultrafiltrate (Figure 1). This section provides a brief review of the structure, interactions, and trafficking of these proteins in the PT. Megalin and cubilin are also expressed both individually and together in other tissues; the reader is referred to an excellent review for a more detailed discussion of their possible functions at those sites (2).

Megalin (also called gp330 or LRP2) is a member of the low-density lipoprotein receptor (LDLR) family of proteins that was originally identified by Kerjaschki \& Farquhar as a major pathogenic antigen in Heymann nephritis in 1982 (3) and found to be equivalent to brushin, a $\sim 600 \mathrm{kDa}$ PT brush border protein previously described by the Muramatsu group (4). Within the kidney, megalin is expressed primarily at the apical surface and in apical endocytic compartments of epithelial cells that comprise the S1 segment of the PT, with decreasing expression in the S2 and S3 segments of the PT. Megalin is also expressed in podocytes, and antigenic responses to megalin in these cells is a primary cause of Heymann nephritis in rats (5).

The sequences of rat and human megalin were reported in 1994 and 1996, respectively (6, 7). Rat megalin contains 4660 amino acids and is a type I transmembrane protein with a large lumenal domain that contains 36 LDLR ligand binding complement type repeat motifs clustered into four domains. These domains are interspersed with epidermal growth factor (EGF)-type repeats and beta propeller spacers characterized by YWTD motifs that mediate ligand dissociation in acidified compartments (see reference 8 for an excellent review on the structure and function of LDLR family member domains). The cytoplasmic tails of all LDL receptor family members are divergent other than the presence of two NPXY motifs that mediate endocytosis; in addition, megalin contains an additional NPXY-like motif VENQNY that may be important for apical delivery of the protein (9). Similar to other members of the LDLR family, megalin also contains an RXRR motif that can be cleaved by furin and related proteases. Cleavage at this site could explain the soluble form observed associated with cells and secreted into the urine (10). Megalin was also demonstrated to undergo regulated intramembrane proteolytic cleavage (11); however, the physiological significance of this is unclear $(12,13)$.

Folding and biosynthetic trafficking of megalin is facilitated by its interaction with the chaperone receptor-associated protein (RAP) that is localized primarily to the endoplasmic reticulum. RAP also accompanies megalin to the plasma membrane $(14,15)$ and dissociates from the receptor in acidified compartments (16). RAP also interacts with the LDLR-related protein LRP. It was proposed that binding to RAP prevents premature interaction of megalin with ligands along the biosynthetic pathway (15).

Early studies aimed at identifying the function of megalin demonstrated that it interacts with several proteins that also bind to LRP, including ApoE and lipoprotein lipase. Since then, interaction of megalin with an increasing number of filtered ligands has been reported (17). An essential role for megalin in the uptake of filtered proteins was cemented in 1996 by the 
demonstration that mice lacking megalin exhibit LMW proteinuria (18) and by the observation that RAP competes with albumin for uptake in microperfused tubules (19).

More recently, another major function was demonstrated for megalin in supplying active lysosomal enzymes to PT cells via their uptake from the tubular lumen. Nielsen et al. (20) found a significant increase in urinary excretion of the freely filtered lysosomal hydrolase cathepsin B in mice with absent or reduced levels of megalin levels and confirmed the direct binding of cathepsin B to megalin. The continuous supply of lysosomal hydrolases to PT lysosomes via this pathway may be necessary to sustain the level of proteolytic function needed to accommodate the apical endocytic load of megalin ligands.

Whereas megalin can bind to many ligands independently, it may require a coreceptor for some interactions. Cubilin is a $460 \mathrm{kDa}$ receptor expressed abundantly in the proximal tubule that interacts with megalin and increases the multiligand binding capability of the complex. Cubilin was originally identified as the receptor for intrinsic factor-vitamin $\mathrm{B}_{12}$ complex in the intestine (21) and was subsequently shown to be identical to a previously described antigen that localized to coated pits in the rat proximal tubule $(22,23)$. The receptor was cloned from rat yolk sac in 1998 and named cubilin based on the presence of 27 tandem CUB (complement C1r/C1s, Uegf, Bmp1) domain repeats that encompass the majority of the protein sequence (24). Unlike megalin, cubilin has no transmembrane domain and requires megalin for its association with the membrane. Cubilin binds to several of the proteins recognized by megalin, including albumin, hemoglobin, RAP, and Ig light chains. Table 1 lists the ligands known to be retrieved by the proximal tubule through their interactions with megalin and cubilin. In addition, cubilin may also bind to other proteins that do not bind to megalin, including transferrin, intrinsic factor-vitamin $\mathrm{B}_{12}$ complex, and apoA1. Cubilin-specific ligands were originally identified in the urine of dogs with mutations in cubilin and in patients with Imerslund-Gräsbeck syndrome, who have vitamin $\mathrm{B}_{12}$ malabsorption. However, there may be some species-specific differences in cubilin binding selectivity, as unlike dogs lacking functional cubilin, cubilin knockout mice showed no increase in urinary excretion of transferrin or apoA1 $(25,26)$.

Cubilin also interacts with amnionless, a 38-50 kDa transmembrane protein that, similar to megalin, contains cytoplasmic NPXY motifs that direct internalization. Amnionless appears to be essential for cubilin transport to the apical surface, as cubilin is retained intracellularly in PT cells of amnionless knockout mice (27). Mutations in amnionless also cause Imerslund-Gräsbeck syndrome (28). Cubilin binds simultaneously to megalin and amnionless (29), but whether and how these three proteins interact functionally at the apical membrane of PT cells remain unclear.

More recently, the ubiquitously expressed MHC-related Fc receptor for $\operatorname{IgG}(\mathrm{FcRN})$ has also emerged as a potential receptor that participates in $\mathrm{IgG}$ and albumin recovery from the ultrafiltrate. This heterodimeric receptor, comprising an MHC class I-like a chain and its obligatory $\beta 2$-microglobulin subunit, binds independently to $\mathrm{IgG}$ and to albumin at acidic $\mathrm{pH}$ but not at neutral $\mathrm{pH}$. FcRN is known to play an important role in salvaging serum IgG and albumin in many nonrenal tissues (reviewed in 30). The current model in these cells is that these proteins are taken up by pinocytosis and bind to FcRN in acidified compartments. 
Proteins that bind to FcRN escape the default route to the degradative pathway and are instead recycled to the cell surface where the increase in $\mathrm{pH}$ causes them to be released. Consistent with this model, FcRN knockout mice have half the levels of serum albumin as normal mice, apparently due to increased degradation kinetics (31).

FcRN is expressed abundantly in the glomerulus and proximal tubule of the kidney. Within the glomerulus, FcRN is expressed at the surface of podocytes and may function to scavenge albumin and immunoglobulins from the basement membrane to limit clogging of the filtration barrier (32). In contrast, in the PT, FcRN binds to soluble albumin that dissociates from megalin/cubilin in acidified endocytic compartments and delivers it via transcytosis to the basolateral surface for reentry into the plasma (33). The extent to which this pathway in the proximal tubule contributes to the maintenance of serum albumin levels remains controversial. One contested parameter is the amount of albumin that actually reaches the PT (nicely reviewed in 34). Another key issue that remains to be addressed is the extent to which transcytosis of albumin occurs in the kidney, and how much of this is mediated by FcRN. Tenten et al. (33) attempted to address the role of FcRN-mediated transcytosis of postfiltered albumin by observing the appearance in serum of tagged albumin expressed selectively in podocytes of control and FcRN knockout mice. Although tagged albumin could be detected in the serum, the capacity of this salvage pathway relative to the degradative pathway in PT cells could not be assessed in this study. Of note, earlier studies assessing the fate of radioiodinated albumin in HK-2 human proximal kidney cells, perfused ex vivo rat kidneys, and microperfused rabbit PTs concluded that the majority of internalized albumin was degraded rather than transcytosed to the basolateral surface $(35,36)$. On balance, the evidence to date remains consistent with the idea that PT reclamation of albumin represents a relatively low-level salvage pathway to recover a small amount of filtered protein rather than a high capacity transcytotic pipeline necessary to maintain serum albumin levels.

\section{CLATHRIN-DEPENDENT ENDOCYTOSIS}

The apical endocytic pathway in PT cells is highly specialized for robust internalization and is uniquely organized for this function (37). Moreover, the capacity for apical endocytosis is both acutely and chronically flexible, as described further in later sections. The preference for apically driven endocytosis and the consequent organization of the endocytic pathway is recapitulated to differing extents in primary and immortalized cell culture models of the PT (38-40). Although in vivo studies have provided a detailed morphological description of the PT endocytic pathway, the lack of an ideal cell culture model system has hampered our ability to understand how endocytosis and recycling are regulated at the molecular level in these cells. To date, our most detailed information about the organization, cellular machinery, and regulation of the apical endocytic pathway in polarized kidney epithelial cells comes from studies conducted in Madin-Darby canine kidney (MDCK) cells, which maintain a limited apical endocytic capacity and are not considered a representative model of the PT (Figure 2). Many PT cell culture models do exist, however, but most are poorly differentiated and lack the apical microvilli characteristic of the PT brush border. Others exhibit relatively poor megalin expression and/or apical endocytic capacity and may better represent S2 or S3 segments of the PT. At present, the opossum kidney (OK) cell line 
remains the preferred cell culture model for the S1 segment of the PT, as it most closely recapitulates PT ion transport functions, expresses megalin, retains a robust apical endocytic capacity, and is well differentiated. In the sections below, we describe briefly the current model for apical endocytosis as elucidated in MDCK cells, compare this with the PT endocytic pathway based on in vivo studies, and attempt to extend this model where possible based on results obtained using cell culture models.

Most cell types possess multiple internalization routes for the uptake of membrane and fluid components. The best studied of these is the clathrin-dependent endocytic pathway, and indeed apical endocytosis in the PT in vivo appears to occur primarily or exclusively via this mechanism, with some unique features described further below. Another major endocytic route that has sometimes been proposed in PT function involves the internalization of receptor ligand complexes and other membrane proteins via caveolae. These are small Ushaped structures enriched in cholesterol, gangliosides, and saturated lipids whose formation is controlled by caveolins (41). However, although some PT immortalized cells express caveolin, this protein is absent from PT cells in vivo (42). For this reason, our discussion below focuses exclusively on clathrin-dependent endocytosis.

Several key features of clathrin-dependent endocytosis are consistent in all cell types. Internalization is initiated by the interaction of membrane receptors and other proteins with adaptor proteins, their incorporation into clathrin-coated invaginations, and budding and fission of these structures. Once these vesicles are uncoated they fuse with each other and/or with slightly acidified early endosomes, where the $\mathrm{pH}$-dependent dissociation of ligands from receptors occurs. Membrane proteins are recycled to the surface in tubular structures that emanate from these endosomes, and the globular portions of endocytic compartments mature into late endosomes. Transient fusion of invaginated late endosomes with lysosomes enables delivery of soluble ligands to these compartments for degradation $(43,44)$. Small GTP-binding proteins termed Rabs are sequentially recruited onto these compartments and in turn activate downstream effectors that mediate changes in phosphoinositide lipid composition and the recruitment of motors and other cytosolic proteins. The remodeling of the organelle surface eventually leads to Rab exchange and recruitment of new effector proteins to gradually alter the identity of these compartments along the endocytic cascade. Although these steps likely also govern the progression of the PT apical endocytic cascade, we lack a detailed understanding of the identity of individual compartments with respect to their Rab profiles or phosphatidylinositol composition. Rather, PT endocytic compartments in vivo have been defined largely using morphological rather than molecular criteria.

In MDCK and many other polarized epithelial cell lines, proteins internalized from the apical plasma membrane via clathrin-dependent pathways enter Rab5-positive early (sorting) endosomes that are slightly acidic ( $\mathrm{pH} \sim 6.9$ ) (reviewed in 45). Membrane proteins can recycle directly to the surface from this compartment via Rab4-positive tubules via a pathway termed fast recycling (46). A subset of membrane proteins escapes this step and traverses a supranuclear recycling compartment of $\mathrm{pH} \sim 6.4$ (47) localized near the centrosome that has subdomains positive for Rab11a, Rab11b, and Rab25 (46, 48). A related recycling compartment marked by Rab8 also receives some apically recycling proteins in addition to cargo internalized from the basolateral surface (49-51). This compartment is 
called the common recycling endosome. The relationship between Rab8- and Rab11-positive compartments remains unclear, and discrepancies in the literature may reflect clonal drift between MDCK cell populations, differentiated state, or other technical differences between studies from different laboratories $(52,53)$. Rab14 is a Rab4 homolog localized to apical endosomes that plays a critical role in apical targeting and tight junction assembly in MDCK cells $(54,55)$. However, Rab14 is expressed at negligible levels in the proximal tubule (56), suggesting a redundant role for other Rabs or a significantly different arrangement of the apical endocytic pathway in PT cells. The proteins that enter recycling endosomes can be returned to the apical surface or enter other compartments deeper in the endocytic pathway.

\section{ORGANIZATION OF THE PROXIMAL TUBULE APICAL ENDOCYTIC PATHWAY}

Only some features of the clathrin-dependent apical endocytic pathway as described in MDCK cells are recapitulated in PT cells in vivo. Indeed, electron microscopy (EM) studies investigating the internalization of filtered fluid-phase and membrane tracers in rodent PTs have provided a very different picture of the apical endocytic pathway $(37,57,58)$. In these studies, rats, mice, or rabbits were administered intravenous injections of the membrane and fluid-phase tracers, and the kidneys were fixed by vascular perfusion at different time intervals to capture the maturation of the endocytic vesicles. Both fluid-phase and membrane cargoes are internalized into clathrin-coated structures that bud from the base of the brush border microvilli $(37,57-60)$. These clathrin-coated invaginations are considerably more irregular in size and shape than those observed in other polarized cells, such as MDCK cells or intestinal epithelial cells in vivo. Studies in OK cells further support the requirement for clathrin in the endocytosis of albumin $(61,62)$. Treatment of these cells with chlorpromazine, an inhibitor of clathrin-dependent endocytosis, or with inhibitors of the GTPase dynamin that regulates vesicle fission from the membrane, led to inhibition of albumin uptake $(61,63)$. In contrast, the cholesterol perturbing drugs filipin and nystatin, which perturb formation of caveolae, had no effect on albumin uptake $(64,65)$.

As noted above, adaptor proteins mediate the interaction of membrane proteins with the underlying clathrin-coated structure. The adaptor protein Disabled-2 (Dab2), which binds to the NPXY motifs of both megalin and the cubilin/amnionless complex, is essential for efficient internalization of these receptors in PT cells $(66,67)$. Another adaptor protein ARH (autosomal recessive hypercholesterolemia) also binds to NPXY motifs and plays a role in LDLR internalization in liver, but ARH is not expressed at appreciable levels in the PT (68, 69).

Once the cargo-containing invaginations have budded from the apical membrane, they release their clathrin coats and fuse with a dense subapical network of tubules $(58,70)$. Within a few minutes after internalization, both membrane and soluble cargo in these compartments can be visualized in large vacuolar compartments termed apical vacuoles (AVs) $(37,58)$. Recycling of membrane receptors and other proteins to the apical surface can occur from both the subapical tubules and from these AVs. Immuno-gold labeling of rat PTs showed localization of antimegalin antibodies in apical tubular compartments that were 
segregated from fluid-phase cargo-containing vesicles, suggesting that fast recycling may occur from these sites (71). In MDCK cells, fast recycling is mediated via Rab4 positive compartments, which interface with the Rab5-positive early endosomal compartments to coordinate rapid recycling of membrane proteins (44). Megalin was found to transit through a Rab4 positive apical tubular compartment in cells of the zebrafish pronephros, suggesting the existence of a rapid recycling pathway in these PTs (72).

For their retrieval to be efficient, ligands must dissociate from megalin and cubilin prior to this fast recycling step. Dissociation is facilitated by acidification of endosomes mediated by the abundantly expressed vacuolar $\mathrm{H}^{+}$-ATPase (V-ATPase), which is present on the PT apical surface and in endosomal compartments. The $\mathrm{pH}$ of the glomerular ultrafiltrate in the lumen is $\sim 7.4$ and decreases to $\sim 5.5$ in apical endosomal compartments. Inhibition of the VATPase in PT cells blocks the delivery of internalized albumin from early endosomes to late endosomes (73). The $2 \mathrm{Cl}^{-} / \mathrm{H}^{+}$antiporter $\mathrm{ClC}-5$ and the sodium hydrogen exchanger NHE3 also contribute to endosomal acidification and are essential for maintaining efficient endocytosis $(74,75)$. As noted above, albumin and $\operatorname{IgG}$ bind more tightly to the FcRN receptor at these lower pHs, and thus some released ligands may switch receptors within endocytic compartments to enable their transcytosis and avoid default delivery to lysosomes (76). Regardless of where this step may occur, a sizable fraction of internalized ligands transit $\mathrm{AVs}$ en route to lysosomal delivery or transcytosis.

EM studies also document tubular structures emanating from AVs that are thought to be enriched in membrane receptors that likely mediate recycling to the apical surface via the "slow recycling" pathway (70). Even this slow recycling pathway is very robust: Nielsen and colleagues (60) concluded from morphological studies in rabbit PT that the amount of membrane area equivalent to that of PT vacuolar compartments was recycled to the apical membrane every $43 \mathrm{~s}$. In contrast, they calculated that it took $23 \mathrm{~min}$ for an equivalent amount of membrane to reach lysosomes.

Functionally, AVs may correspond to the Rab11-positive apical recycling endosome that mediates slow recycling in MDCK cells. Expression of fluorescently tagged Rab11a in primary PT cells isolated from mouse kidney cortex revealed numerous highly dynamic spherical structures of varying sizes (40). Tubules could be visualized emerging from these compartments, similar to those observed in EM studies of AVs $(40,70)$. These structures did not colocalize with markers of early sorting endosomes, including Rab4, Rab5, or EEA1. However, unlike the tubular Rab11a compartments in MDCK and other cells, fluid-phase markers readily access Rab11a-positive structures in these primary PT cells (40). These data suggest that AVs have hybrid properties of the sorting and recycling endosomes described in MDCK cells. However, it is unclear to what extent the AV compartment is maintained in immortalized PT cell cultures, as Rab11a exhibits strikingly dissimilar distribution patterns in different PT cell lines (Y. Rbaibi and O. Weisz, unpublished observation). Whether the sorting of membrane from fluid in these large spherical structures is an adaptation that enables PT cells to maintain their high endocytic capacity is unknown. Regardless, the physical demands of generating tubules from such large structures raises interesting questions about the lipid remodeling that likely accompanies this process as well as the identity of the proteins that regulate recycling from AVs. 
In addition to Rabs 4, 5, and 11, a role for Rab38 in apical endocytosis in PT cells has recently emerged. Fawn-hooded hypertensive rats present with high LMW proteinuria, apparently due to knockout of this GTPase. Ectopic expression of Rab38 rescues the proteinuric phenotype in the rats, consistent with the idea that Rab38 is a critically important component of the cascade in mediating and regulating apical endocytosis in proximal tubule epithelia (77). In other tissues, Rab38 is associated with lysosomal-related organelles including melanosomes, but its localization in PT cells is unknown.

Endocytosis of megalin/cubilin ligands is also highly dependent on the integrity of the actin cytoskeleton. Myosin motors and/or actin dynamics likely play a role in multiple steps in multiligand receptor-mediated endocytosis in the PT, including trafficking of receptors from the brush border into coated pits at the base of these structures, invagination of clathrincoated pits, movement and fusion of early endosomes, and recycling. Disruption of F-actin in OK cells using cytochalasins reduced endocytosis of albumin by $50-95 \%(61,78)$. Myosin IIA, myosin VI, and more recently, myosin 9a were implicated in PT endocytosis (79-81), and knockout of Myo9a or myosin VI in mouse models causes LMW proteinuria $(79,81)$. Megalin interacts with the heavy chain of nonmuscle myosin IIA via its adaptor Dab2, and this interaction appears to be important for endocytosis, as the myosin II inhibitor blebbistatin inhibits lactoferrin uptake in L2 yolk sac cells (80). Similarly, myosin VI binds to Dab2 as well as to the PDZ-domain-containing adaptor protein GIPC (82). How these distinct motor proteins cooperate to mediate efficient endocytosis is not yet clear.

In addition to the actin cytoskeleton, the microtubule network is essential for efficient uptake of megalin ligands. Depolymerization of microtubules using nocodazole reduced endocytosis by $>55 \%$ (61) and loss of endocytic vacuoles was observed in the PT of rats treated for $5 \mathrm{~h}$ with colchicine (83). Additionally, the microtubule motor kinesin 3B (KIF3B) was implicated in PT endocytosis. KIF3B interacts with the carboxy-terminus of ClC-5, a $2 \mathrm{Cl}^{-} / \mathrm{H}^{+}$antiporter mutated in Dent disease that is required for efficient apical internalization. Overexpression of KIF3B reduced the surface expression of ClC-5 and inhibited albumin uptake in OK cells (84). Additionally, the carboxy terminus of ClC-5 interacts with the actin-depolymerizing protein cofilin, and phosphorylation of cofilin by overexpression of LIM kinase I inhibited albumin uptake in LLC-PK1 and OK cells (85). Sequential interactions between $\mathrm{ClC}-5$ and these cytoskeletal machinery components may help to propel endocytic vesicles through the dense actin network beneath the brush border and toward compartments deeper in the apical cytoplasm.

\section{Regulation of Proximal Tubule Apical Endocytic Capacity}

The apical endocytic pathway in PT cells is uniquely plastic, and acute and chronic stimuli can increase or decrease endocytic capacity. An interesting feature of this malleability is the potential role of megalin itself in modulating apical endocytic pathway differentiation. Conversely, changes in endocytic load can alter the apical expression of megalin. It is unclear how this interdependent regulation of megalin expression and the elaboration of the apical endocytic pathway are accomplished, but as described below, numerous signaling pathways contribute. Another unresolved question is whether this intricate sensing mechanism is fully recapitulated in cell culture models of the PT. 
Several in vivo studies show that PT cells in which expression of the multiligand receptors is reduced or absent have markedly fewer apical endocytic compartments and/or impaired uptake of fluid-phase markers, consistent with a global defect in endocytosis. EM analysis of megalin knockout mice showed no gross morphological changes in PT cell structure but revealed dramatic ultrastructural changes in the apical endocytic pathway, including the loss of clathrin-coated pits, endosomes, and lysosomes (18). Similar results were recently reported in a kidney biopsy specimen from a Donnai-Barrow patient harboring a mutation in megalin (86). Additionally, knockout of megalin in zebrafish larvae results in the disappearance of Rab4-positive apical endosomes from the pronephros and impairs the endocytic uptake of both membrane-bound and fluid-phase cargo (87). Although the morphology of the PT endocytic pathway is apparently normal in ClC-5 knockout mice that have dramatically reduced levels of megalin, the uptake of fluid-phase markers is severely impaired (88-90). Additionally, Chou et al. (91) recently reported that loss of the CLIC4 chloride channel also results in reduced megalin levels as well as fewer endocytic compartments in the PT of knockout mice.

A critical step in the modulation of megalin endocytosis is interaction with its adaptor protein Dab2. Dab2 knockout mice present with mild LMW proteinuria that underscores the role Dab2 plays in clearing LMW proteins from the glomerular filtrate (92). Moreover, knockdown of Dab2 in mice causes a decrease in megalin protein expression along with its redistribution from endosomes to the cell surface (93). Conversely, knockdown of megalin abolished Dab2 staining in the kidney, suggesting that expression of the two proteins is interdependent (93).

Recent studies by Erkan and colleagues demonstrate that phosphorylation of Dab2 by Akt (also known as protein kinase $\mathrm{B}$ and henceforth referred to as $\mathrm{Akt} / \mathrm{PKB}$ ) is important for albumin endocytosis in PT cells. Mutation of the phosphorylated serine residues on Dab2 caused its loss from the cell surface and reduced albumin uptake in human HKC-8 cells (94). Additionally, overexpression of Akt/PKB stimulated albumin uptake, whereas knockdown had the converse effect $(94,95)$. Angiotensin II, acting via the $\mathrm{AT}_{2}$ receptor, also stimulates albumin endocytosis in LLC-PK1 cells by the activation of Akt/PKB via its upstream regulator phosphatidylinositol 3-kinase (PI3K) (96). Consistent with this pathway is the observation that PI3K inhibitors decrease endocytosis of albumin in OK cells $(97,98)$. The effect on endocytosis is likely a function of megalin degradation resulting from its sequestration in vacuolated endosomal compartments (97). In contrast, addition of angiotensin II to OK cells expressing $\mathrm{AT}_{1 \mathrm{~A}}$ receptors led to a decrease in megalin mRNA and protein levels with consequent effects on albumin uptake. This effect required ERK signaling and was completed by the insulin-mediated activation of PI3K (99). Thus, cross talk between $\mathrm{AT}_{1 \mathrm{~A}}$ and $\mathrm{AT}_{2}$ receptors may modulate the level of megalin expression in $\mathrm{PT}$ cells. TNF- $a$ also triggers ERK signaling leading to a downregulation of megalin levels (100).

$\mathrm{Akt} / \mathrm{PKB}$ and Dab2 also play a central role in the cellular response to albumin overload in the PT resulting from compromise of the glomerular filtration barrier. High concentrations of albumin lead to PT apoptosis, though this response may be initiated by fatty acids bound to albumin rather than by albumin itself (101). Overnight exposure of human HKC-8 and 
porcine LLC-PK1 cells to high concentrations of albumin results in decreased expression of both Dab2 and Akt/PKB as well as megalin $(95,102)$, without alteration of fluid-phase endocytosis (103). Elevated albumin levels also trigger MAPK pathway activation mediated by upregulation of the epidermal growth factor receptor and induce TGF- $\beta 1$ secretion via a cascade that requires Dab2 $(104,105)$. TGF- $\beta 1$ in turn downregulates megalin and cubilin expression via a Smad2/Smad3-dependent transcriptional response (106).

Another signaling axis that regulates megalin endocytosis may be mediated by binding of megalin to the scaffolding proteins NHERF-1 and NHERF-2 (107, 108). NHERF-2 also binds to ClC-5 (108), and this complex may also include NHE3 (109), the V-ATPase, the cytosolic aspartyl aminopeptidase DNPEP (110), and Nedd4-2. In support of a functional role for this scaffold, Poronnik and colleagues (111) have demonstrated that altering the activity of the ion transporters associated with megalin modulates the efficiency of albumin uptake. Phosphorylation of NHE3 by Sgk-1 stimulates NHE3 activity, and silencing of Nedd4-2 or Sgk-1 reduced albumin endocytosis in OK cells (111). Interestingly, a mouse knockout of another scaffolding protein, Shank2 (also called cortactin-binding protein CortBP), was recently reported to exhibit markedly reduced numbers of PT endocytic vesicles and decreased PT albumin uptake compared with control mice (112). Shank2 interacts with actin and dynamin and is known to regulate the endocytosis of the sodium phosphate cotransporter NaPiIIa, but whether it binds to megalin is unknown.

Yet an additional regulator of PT apical endocytic capacity is the fluid shear stress (FSS) that accompanies the flow of ultrafiltrate through the tubular lumen. Acute exposure of OK and other PT cell lines to FSS leads to a two- to threefold increase in endocytosis $(63,113)$. The effect of FSS on endocytosis includes enhanced uptake of both albumin and fluid-phase markers, suggesting that global endocytic capacity, rather than solely receptor-mediated endocytosis, is stimulated. A possible regulator of this pathway could be the Rab5 adaptor rabankyrin-5, which is expressed in apical endocytic compartments in the PT and has been demonstrated to modulate endocytic uptake of fluid-phase markers through Rab5 positive apical compartments in nonpolarized cells (114). The acute endocytic response to flow requires the primary cilia, ATP release, purinergic signaling, and an increase in intracellular calcium (63). It is unclear whether this is accompanied by changes in Akt/PKB activation and Dab2 phosphorylation or alternatively, with changes in megalin interactions with scaffolding proteins and ion transporters as described above. Interestingly, exposure to FSS also has an opposing effect on several transporters and other receptors, causing surface accumulation of AQP1, NHE3, the V-ATPase, and the angiotensin receptor AT1 (115-117). This increase in surface transporters is consistent with the functional need of the PT to increase fluid and ion uptake across the PT in response to increased glomerular filtration rate. It is unknown whether the redistribution of these proteins occurs via increased recycling and/or surface retention.

\section{ENDOCYTIC UPTAKE IN INHERITED AND ACQUIRED DISORDERS}

Impaired PT endocytosis resulting from genetic mutations or acute or chronic insults to kidney function manifests as LMW or tubular proteinuria. Numerous acquired conditions are associated with LMW proteinuria, including acute kidney injury, ischemia-reperfusion 
injury, kidney transplantation, the early stages of diabetes, and heavy metal poisoning.

Below we discuss our current understanding of the molecular mechanisms underlying three examples of genetic diseases that manifest with tubular proteinuria. The effects of rare megalin and cubilin mutations on human PT function were nicely reviewed recently (118) and are not discussed here due to space limitations.

\section{Cystinosis}

Cystinosis is an autosomal recessive disease (prevalence approximately 1 in 100,000) caused by mutations in the CTNS gene that encodes for the lysosomal protein cystinosin, which transports cystine from degraded proteins to the cytosol for reuse (119). This disease affects numerous organs and is the most common cause of inherited renal Fanconi syndrome, characterized by rickets, tubular proteinuria, aminoaciduria, glucosuria, and phosphaturia. The most prevalent (95\%) and severe form is infantile nephropathic cystinosis, which is characterized by onset within the first year of life and typically results in end-stage renal disease within a decade. However, there is significant variability in disease severity, with milder juvenile and adult onset variants characterized by less severe kidney disease and by only ocular symptoms, respectively. The most prevalent therapy for cystinosis is cysteamine, which reduces cellular cysteine levels and slows progression of the disease in many organs. Unfortunately, cysteamine does not relieve Fanconi syndrome. Lack of functional CTNS eventually leads to increased apoptosis of PT cells and the so-called swan-neck deformity characterized by gradual flattening of the epithelial tubule cells in the Bowman capsule, leading to eventual dilation of the PT. Apoptosis is likely due to increased oxidative stress characterized by an increased ratio of oxidized to reduced glutathione, which ultimately compromises mitochondrial function. Increased numbers of autophagosomes were observed in renal PT cells from patients with nephropathic cystinosis and may contribute to the increased apoptosis as inhibitors of autophagy attenuated cell death (120). However, whether these changes in and oxidative stress and autophagy are related directly to the cellular accumulation of cystine was recently questioned (121).

In a recent elegant study, Courtoy and colleagues (122) characterized in detail the temporal changes in PT structure and function using the $\mathrm{Ctns}^{-/-}$mouse model. Importantly, this study suggests that loss of PT endocytic function and cell differentiation temporally precedes apoptosis and development of the swan-neck deformity. Lysosomal swelling and PT dedifferentiation in $\mathrm{Ctns}^{-{ }^{-}}$mice were evident early in the disease state. Moreover, whereas an early report found no change in megalin or cubilin expression in kidney sections from a patient (123), quantitative PCR and in situ hybridization of $\mathrm{Ctns}^{-1-}$ mouse kidneys and immunoperoxidase staining of kidney samples from cystinotic patients revealed a progressive loss of megalin and cubilin expression (122). Endocytosis of tagged ovalbumin or $\beta 2$-microglobulin was also reduced in $\mathrm{S} 1$ segments of $\mathrm{Ctns}^{-1}$ mice compared with wildtype mice, whereas enhanced endocytosis of these markers was observed in S3 segments (122). The authors speculate that the disease may initiate in the glomerulotubular boundary and S1 segment of the PT because of the high content of cysteine residues in reclaimed albumin (17 per molecule). Subsequent dedifferentiation and loss of megalin/cubilin expression in the upstream segments could expose downstream segments to the toxic effects of filtered proteins that may contribute to progressive extension of the swan-neck lesion. 
A recent study documented lower expression of the lysosomally expressed Rab27a in kidneys of $\mathrm{Ctns}^{-1-}$ mice as well as in PT cells from a cystinosis patient compared with control samples (124). Rab27a was recently implicated in lysosomal exocytosis.

Additionally, expression of constitutively active Rab27a (and to a lesser extent, constitutively active Rab7) in $\mathrm{Ctns}^{-1-}$ fibroblasts increased lysosomal dynamics, suppressed expression of ER stress markers, and reduced cellular cystine levels. The authors suggested but could not demonstrate that correction of these phenotypes is due to increased exocytosis of lysosomal contents mediated by Rab27a. Whether increasing Rab27a activity in the PT would also alleviate these phenotypes is an important question that remains to be assessed.

\section{Dent Disease}

Dent disease is a heterotypic $\mathrm{X}$-linked disease caused primarily by mutations in CLCN5, which encodes the electrogenic $\mathrm{Cl}^{-} / \mathrm{H}^{+}$exchanger $\mathrm{ClC}-5$ (see 125 for review). Dent disease patients uniformly present with LMW proteinuria and frequently also develop hypercalciuria, nephrocalcinosis, kidney stones, hematuria, hypophosphatemia, or renal insufficiency. Even $70 \%$ of female carriers show some LMW proteinuria. A subset of patients have Dent2 disease, which is caused by mutations in OCRL rather than in CLCN5, and may also have mild extrarenal impairments, including hypotonia, cataracts, and metal deficiencies. It remains unclear how these $O C R L$ mutations cause primarily kidney disease rather than the more severe Lowe syndrome phenotype described below. Other genes also cause Dent disease, as roughly $30 \%$ of patients have neither mutations in CLCN5 nor OCRL1.

ClC-5 is expressed primarily in the PT, with highest expression in the $\mathrm{S} 1$ segment, and also in the intercalated cells of the collecting duct. In the PT, it is localized primarily to subapical endosomes that also contain the V-ATPase (126). A small fraction is also present at the plasma membrane, where it interacts with megalin, KIF3A, and a variety of scaffolding proteins as noted above.

The LMW proteinuria observed in patients is recapitulated in ClC-5 mouse knockouts (90, 127). This reflects the reduced uptake of filtered proteins by the PT, which is particularly evident when examining cross sections of proximal tubules in kidneys from female heterozygotes, where random X-chromosome inactivation leads to chimeric tubules (127). In these sections, those patches of cells lacking ClC-5 display markedly less uptake of both a fluid-phase marker (horseradish peroxidase) and the megalin ligand $\beta 2$-microglobulin. Loss of ClC-5 also impairs delivery of internalized proteins and fluid-phase tracers to lysosomes (88) and causes an increase in the urinary excretion of lysosomal hydrolases (20).

Strikingly, a dramatic reduction in the levels of megalin protein (but not mRNA; see 88) is observed in cells lacking ClC-5 (127), along with the redistribution of the residual megalin to intracellular compartments (88). These effects of $\mathrm{ClC}-5$ on endocytosis are apparently unique to the PT, as the loss of ClC-5 expression does not perturb megalin levels or thyroglobulin uptake in the thyroid of ClC-5 knockout mice (128) or endocytosis in the liver (127). Surprisingly, whereas the amount of megalin shed into the urine was lower in knockout mice (as expected given the decreased level of this protein), no change in cubilin shedding was observed (88). 
The reduction in megalin expression and the defective endocytic pathway also contribute to other renal impairments in Dent disease patients. For example, the variable presence of renal hypercalciuria and kidney stones in these patients, as well as in the two knockout mouse strains that have been generated, may be due to increased signaling in downstream segments of the PT by parathyroid hormone (PTH) because its megalin-dependent endocytosis is deficient in the $\mathrm{S} 1$ segment. Increased PTH signaling would normally stimulate hydroxylation of $25(\mathrm{OH})$-vitamin $\mathrm{D}_{3}$ to mobilize calcium. However this is counteracted by the concurrent loss of $25(\mathrm{OH})$-vitamin $\mathrm{D}_{3}$ in the urine (because its uptake is dependent on megalin/cubilin function), and the resulting balance between these opposing effects likely dictates urinary calcium levels (127).

Unlike PT cells from megalin knockout mice, which show a dramatic loss of endocytic structures in PT cells, ultrastructural studies of the endocytic apparatus in PT cells from Dent patient biopsies and from the knockout mice reveal no obvious morphological changes (88-90). Moreover, normal levels of Rab5a and Rab7 proteins were present in PT samples from the knockout mice (88), although one study found an inversion in the localization of the normally apical V-ATPase to the basolateral surface in PT cells lacking ClC-5 (89). Thus, the presence of residual megalin in the PT is apparently sufficient to maintain normal endocytic morphology. However, the observed impairment in endocytosis cannot be due simply to the decreased megalin expression, as multiple studies have reported reduced uptake of fluid-phase markers in PT cells lacking functional ClC-5 $(88,90,127,129)$.

In vitro studies in mice show that $\mathrm{ClC}-5$ is required for normal endosomal acidification, and although this was originally assumed to underlie the observed PT endocytic defects, the role of ClC-5 in apical endocytosis has remained murky, particularly because ClC-5 was discovered to be an electrogenic $\left(2 \mathrm{Cl}^{-} / \mathrm{H}^{+}\right)$exchanger rather than a $\mathrm{Cl}^{-}$channel as originally assumed (75). To test whether defective acidification per se is responsible for the impaired endocytosis and other renal phenotypes, Jentsch and colleagues (130) replaced wild-type ClC-5 in mice with a point mutant that functions as an uncoupled $\mathrm{Cl}^{-}$channel rather than as an electrogenic $\mathrm{Cl}^{-} / \mathrm{H}^{+}$exchanger. Renal cortical vesicles isolated from these mice demonstrated normal acidification, but strikingly, the mice had the same renal phenotype as CLC5N knockout mice, and apical endocytosis in the PT was impaired (130). Thus, endosomal $\mathrm{Cl}$ concentration itself, rather than $\mathrm{pH}$, appears to drive endocytic efficiency in PT cells. Consistent with this, Gorvin et al. (129) more recently demonstrated that not all disease-causing mutations of ClC-5 impair acidification.

An alternative explanation for the finding that defective acidification is not responsible for the endocytic defect is that the major functional role for $\mathrm{ClC}-5$ could be at the plasma membrane. Indeed, the endocytic defect appears to occur at a very early step in internalization (90). ClC-5 interacts with numerous scaffolding proteins as well as megalin. Interaction of $\mathrm{ClC}-5$ with cofilin at the apical surface might enable localized actin depolymerization to enable more efficient invagination or fission of clathrin-coated pits (85). Alternatively, interaction of ClC-5 with the kinesin motor KIF3B may be important for the transport of ClC-5-containing vesicles and for albumin uptake (84). Additionally, binding of the PY motif of ClC-5 to the ubiquitin ligase Nedd4-2 might mediate the observed negative effect of decreasing Nedd4-2 levels or activity on albumin uptake efficiency (111). However, 
mutation of the PY motif of ClC-5 in mice has no effect on megalin levels or receptormediated or fluid-phase endocytosis and did not result in LMW proteinuria (131). Although no increase in plasma membrane expression of this mutant ClC-5 in mice could be observed using immunohistochemistry, similar mutations block ClC-5 endocytosis and elevate ClC-5 surface expression in oocytes and in cell culture $(111,132)$. More insight into the function of ClC-5 in apical endocytosis may eventually come from studies on OCRL1, which is localized largely to compartments distinct from $\mathrm{ClC}-5$ (see below) and yet results in a very similar renal phenotype when mutated.

\section{Lowe Syndrome}

Lowe syndrome is an X-linked recessive disorder caused by mutations in OCRL, which encodes OCRL1, a phosphatidylinositol 5' -phosphatase. Individuals with Lowe syndrome exhibit congenital cataracts, hypotonia, intellectual disability, and proximal renal tubular dysfunction. The renal abnormalities in Lowe syndrome, which include renal tubular acidosis and LMW proteinuria, are virtually identical to those observed in patients with Dent disease. Lowe syndrome patients typically develop end-stage renal disease within the first 20 years of life, and this is the primary cause of mortality (see 133 for a review). As noted above, a subset of patients with OCRL mutations manifest with milder extrarenal symptoms and are classified as having Dent2 disease.

OCRL1 is a $97 \mathrm{kDa}$ cytosolic protein expressed throughout the body, with highest expression levels in the brain, liver, and kidney. OCRL1 is found in largest amounts at the trans-Golgi network (134). It is also localized to clathrin-coated pits, early and recycling endosomes, cilia basal bodies, tight junctions, and at the intercellular bridge that forms during cytokinesis (135).

Ocrl knockout mice exhibit no symptoms of the disease due to the redundant function of another phosphatidylinositol $5^{\prime}$-phosphatase, Inpp $5 b$. Mouse Inpp $5 b$ is expressed at higher levels and with different splice patterns than human INPP5B, which likely accounts for the compensation observed (136). To address this, a second knockout mouse model was designed in which both $O c r l$ and Inpp $5 b$ were knocked out and human INPP5B was overexpressed. These mice exhibit LMW proteinuria and aminoaciduria as observed in Lowe syndrome patients (137). However, no extrarenal phenotypes of this mouse model have yet been reported.

OCRL1 is capable of hydrolyzing the $5^{\prime}$-phosphate from both $\operatorname{PtdIns}(4,5) \mathrm{P}_{2}$ and PtdIns $(3,4,5) \mathrm{P}_{3}$ to generate PtdIns $4 \mathrm{P}$ and PtdIns $3,4 \mathrm{P}_{2}$, respectively, and in vitro has preference for the former (138). Mutations in OCRL1 that cause Lowe syndrome are localized throughout the gene, but all of those tested to date result in dramatically reduced enzymatic activity. Loss of OCRL1 function leads to a slight increase in cellular $\operatorname{PtdIns}(4,5) \mathrm{P}_{2}$ levels, but it remains unclear how this defect in phosphatidylinositol metabolism results in the Lowe syndrome phenotype.

Phosphatidylinositols play numerous roles in cell function, including marking organelle identity, modulating cytoskeletal dynamics, and regulating membrane traffic. Most PtdIns $(4,5) \mathrm{P}_{2}$ in cells is present at the plasma membrane, where it regulates signal 
transduction, ion transport, and endocytosis. Along with the localization of OCRL1 to the TGN and endocytic compartments, this has led investigators to hypothesize a role for OCRL1 in vesicular transport. Consistent with this, OCRL1 interacts with clathrin AP-2, APPL1 and related proteins, and a large number of Rab GTPases. Additionally, OCRL1 likely plays a role in actin dynamics through control of PtdIns $(4,5) \mathrm{P}_{2}$ levels, and patient fibroblasts or cells depleted of OCRL1 show increased formation of actin comets $(139,140)$.

Patients with Lowe syndrome have increased plasma and urinary levels of lysosomal hydrolases $(133,141)$. It is still unclear, however, whether the elevated urinary secretion of lysosomal hydrolases is due to defective M6P-receptor trafficking in cells lacking OCRL1 $(142,143)$ or to impaired uptake of filtered hydrolases from the tubule lumen, as observed in megalin and ClC-5 knockout mice (144).

There is less consensus about a direct role for OCRL1 in endocytosis and/or recycling. Despite the colocalization of a fraction of OCRL1 with clathrin-coated pits and very early endosomes, only one study has reported a (minor) delay in transferrin uptake and accumulation of late-stage clathrin-coated pits in patient fibroblasts. This was attributed to a defect in the depolymerization of actin surrounding internalized clathrin-coated pits (145). Additionally, fluorescence-based assays revealed modest defects in transferrin and megalin recycling in Hela and HK-2 cells, respectively $(146,147)$. The effects of OCRL1 knockdown on recycling were attributed to defective uncoating of actin on recycling endosomes (147). By contrast, no effects in the degradation kinetics of a radioiodinated megalin ligand in HK-2 and MDCK cells depleted of OCRL1 were observed in another study (143).

A significant limitation in translating the findings above into an understanding of how the lack of OCRL1 leads to LMW proteinuria is the lack of a well-differentiated PT cell model in which to study apical membrane traffic. Another concern is that the relatively subtle trafficking defects reported in these studies is far less than the dramatic effects on membrane traffic reported in PTs lacking CLC-5. The recent availability of a mouse cell model (137) that replicates the Lowe syndrome kidney phenotype is anticipated to be of significant benefit in this regard. Additionally, an intriguing recent study in zebrafish found dramatically reduced levels of megalin in the pronephric kidney of OCRL1 knockout transgenic zebrafish. This was accompanied by the loss of early endosomes and the appearance of enlarged vacuoles that accumulated residual megalin (148). The reduction in megalin expression is similar to that reported in the Dent disease mouse model and consistent with the reported reduction in levels of shed megalin in the urine of Lowe syndrome and Dent disease patients. In contrast, OCRL1 knockdown in HK-2 cells had no effect on total megalin levels, although the amount at the cell surface was reduced (147).

In addition to its reported roles in membrane traffic and actin dynamics, OCRL1 is involved in several other cellular functions, including ciliary biogenesis, junctional complex maturation, and cell division (135). Transient knockdown of OCRL1 in zebrafish and in multiple mammalian cell lines results in ciliary lengthening or shortening. However, no defects in ciliogenesis were observed in the transgenic zebrafish OCRL knockout model (148). The lack of consistent results and the absence of hallmark characteristics of 
ciliopathies, including renal cysts, in Lowe syndrome patients suggest that ciliary defects are not the primary cause of Lowe syndrome.

A final suggested role for OCRL1 is in cell proliferation and cytokinesis. OCRL1 was reported to interact with Rab35 at intracellular bridges during abscission. OCRL1-dependent actin remodeling is necessary for complete cell division in a cell line derived from the kidney of a Lowe syndrome patient (149). It remains unknown whether and how this defect in cell division contributes to the spectrum of Lowe syndrome symptoms.

\section{SUMMARY AND OPEN QUESTIONS}

PT cells are highly specialized for the apical uptake of filtered proteins and other ligands via the multiligand receptors megalin and cubilin. Ultrastructural studies have provided a good understanding of how the apical endocytic pathway is organized in PT cells, and the morphology of these compartments is significantly different than those identified in other polarized kidney cells. At present, our model lacks critical information about the associated Rabs and phosphatidylinositol lipid species needed to identify these compartments, as well as the machinery that regulates traffic between these compartments. A clearer understanding of the molecules associated with each compartment may in turn may shed light on the specific functional requirements of PT trafficking that necessitate elaboration of the unique features of this pathway.

Apical endocytosis in the PT is highly adaptable to physiologic need and can rapidly lead to alterations in internalization capacity. Sometimes this can lead to morphologically discernible changes in the size and number of endocytic compartments. Interestingly, expression of megalin itself seems to play a role in the elaboration of the endocytic pathway, in that knockout of megalin leads to diminution of this pathway. However, it remains elusive how signaling by megalin and its adaptor protein Dab2 mediate this response.

Impaired apical endocytosis in the PT results in tubular proteinuria and is observed in many acute, chronic, and genetic diseases. Sustained exposure of downstream nephron segments to filtered proteins triggers further damage and eventually leads to renal failure. Although we know the molecular basis of these diseases, we lack a detailed understanding of how loss of function of these proteins impairs the endocytic pathway. Addressing these questions is essential for understanding the cellular response to disease and for developing therapies to modulate endocytic function.

\section{Acknowledgments}

We apologize to the many authors whose work we are unable to cite directly due to space limitations. Studies on membrane trafficking in the proximal tubule cells in the Weisz laboratory are supported by National Institutes of Health grants DK101484 and DK100357.

\section{LITERATURE CITED}

1. Vinge L, Lees GE, Nielsen R, Kashtan CE, Bahr A, Christensen EI. The effect of progressive glomerular disease on megalin-mediated endocytosis in the kidney. Nephrol Dial Transpl. 2010; 25:2458-67. 
2. Moestrup SK, Verroust PJ. Megalin- and cubilin-mediated endocytosis of protein-bound vitamins, lipids, and hormones in polarized epithelia. Annu Rev Nutr. 2001; 21:407-28. [PubMed: 11375443]

3. Kerjaschki D, Farquhar MG. The pathogenic antigen of Heymann nephritis is a membrane glycoprotein of the renal proximal tubule brush border. PNAS. 1982; 79:5557-61. [PubMed: 6752952]

4. Ozawa M, Yonezawa S, Sato E, Muramatsu T. A new glycoprotein antigen common to teratocarcinoma, visceral endoderm, and renal tubular brush border. Dev Biol. 1982; 91:351-59. [PubMed: 6178634]

5. Farquhar MG, Saito A, Kerjaschki D, Orlando RA. The Heymann nephritis antigenic complex: megalin (gp330) and RAP. J Am Soc Nephrol. 1995; 6:35-47. [PubMed: 7579068]

6. Saito A, Pietromonaco S, Loo AK, Farquhar MG. Complete cloning and sequencing of rat gp330/ "megalin," a distinctive member of the low density lipoprotein receptor gene family. PNAS. 1994; 91:9725-9. [PubMed: 7937880]

7. Hjälm G, Murray E, Crumley G, Harazim W, Lundgren S, et al. Cloning and sequencing of human gp330, a Ca ${ }^{2+}$-binding receptor with potential intracellular signaling properties. Eur J Biochem. 1996; 239:132-37. [PubMed: 8706697]

8. Jeon H, Blacklow SC. Structure and physiologic function of the low-density lipoprotein receptor. Annu Rev Biochem. 2005; 74:535-62. [PubMed: 15952897]

9. Takeda T, Yamazaki H, Farquhar MG. Identification of an apical sorting determinant in the cytoplasmic tail of megalin. Am J Physiol Cell Physiol. 2003; 284:C1105-13. [PubMed: 12519751]

10. Bachinsky DR, Zheng G, Niles JL, McLaughlin M, Abbate M, et al. Detection of two forms of GP330. Their role in Heymann nephritis. Am J Pathol. 1993; 143:598-611. [PubMed: 8342605]

11. Zou Z, Chung B, Nguyen T, Mentone S, Thomson B, Biemesderfer D. Linking receptor-mediated endocytosis and cell signaling: evidence for regulated intramembrane proteolysis of megalin in proximal tubule. J Biol Chem. 2004; 279:34302-10. [PubMed: 15180987]

12. Christ A, Terryn S, Schmidt V, Christensen EI, Huska MR, et al. The soluble intracellular domain of megalin does not affect renal proximal tubular function in vivo. Kidney Int. 2010; 78:473-77. [PubMed: 20531455]

13. Li Y, Cong R, Biemesderfer D. The $\mathrm{COOH}$ terminus of megalin regulates gene expression in opossum kidney proximal tubule cells. Am J Physiol Cell Physiol. 2008; 295:C529-37. [PubMed: 18495814]

14. Birn H, Vorum H, Verroust PJ, Moestrup SK, Christensen EI. Receptor-associated protein is important for normal processing of megalin in kidney proximal tubules. J Am Soc Nephrol. 2000; 11:191-202. [PubMed: 10665926]

15. Willnow TE, Rohlmann A, Horton J, Otani H, Braun JR, et al. RAP, a specialized chaperone, prevents ligand-induced ER retention and degradation of LDL receptor-related endocytic receptors. EMBO J. 1996; 15:2632-39. [PubMed: 8654360]

16. Czekay RP, Orlando RA, Woodward L, Lundstrom M, Farquhar MG. Endocytic trafficking of megalin/RAP complexes: dissociation of the complexes in late endosomes. Mol Biol Cell. 1997; 8:517-32. [PubMed: 9188102]

17. Christensen EI, Birn H, Storm T, Weyer K, Nielsen R. Endocytic receptors in the renal proximal tubule. Physiology. 2012; 27:223-36. [PubMed: 22875453]

18. Leheste JR, Rolinski B, Vorum H, Hilpert J, Nykjaer A, et al. Megalin knockout mice as an animal model of low molecular weight proteinuria. Am J Pathol. 1999; 155:1361-70. [PubMed: 10514418]

19. Cui S, Verroust PJ, Moestrup SK, Christensen EI. Megalin/gp330 mediates uptake of albumin in renal proximal tubule. Am J Physiol. 1996; 271:F900-7. [PubMed: 8898021]

20. Nielsen R, Courtoy PJ, Jacobsen C, Dom G, Lima WR, et al. Endocytosis provides a major alternative pathway for lysosomal biogenesis in kidney proximal tubular cells. PNAS. 2007; 104:5407-12. [PubMed: 17369355]

21. Seetharam B, Alpers DH, Allen RH. Isolation and characterization of the ileal receptor for intrinsic factor-cobalamin. J Biol Chem. 1981; 256:3785-90. [PubMed: 6260778] 
22. Seetharam B, Christensen EI, Moestrup SK, Hammond TG, Verroust PJ. Identification of rat yolk sac target protein of teratogenic antibodies, gp280, as intrinsic factor-cobalamin receptor. J Clin Investig. 1997; 99:2317-22. [PubMed: 9153271]

23. Sahali D, Mulliez N, Chatelet F, Dupuis R, Ronco P, Verroust P. Characterization of a 280-kD protein restricted to the coated pits of the renal brush border and the epithelial cells of the yolk sac. Teratogenic effect of the specific monoclonal antibodies. J Exp Med. 1988; 167:213-18. [PubMed: 2891781]

24. Moestrup SK, Kozyraki R, Kristiansen M, Kaysen JH, Rasmussen HH, et al. The intrinsic factorvitamin B12 receptor and target of teratogenic antibodies is a megalin-binding peripheral membrane protein with homology to developmental proteins. J Biol Chem. 1998; 273:5235-42. [PubMed: 9478979]

25. Amsellem S, Gburek J, Hamard G, Nielsen R, Willnow TE, et al. Cubilin is essential for albumin reabsorption in the renal proximal tubule. J Am Soc Nephrol. 2010; 21:1859-67. [PubMed: 20798259]

26. Kozyraki R, Fyfe J, Verroust PJ, Jacobsen C, Dautry-Varsat A, et al. Megalin-dependent cubilinmediated endocytosis is a major pathway for the apical uptake of transferrin in polarized epithelia. PNAS. 2001; 98:12491-96. [PubMed: 11606717]

27. Strope S, Rivi R, Metzger T, Manova K, Lacy E. Mouse amnionless, which is required for primitive streak assembly, mediates cell-surface localization and endocytic function of cubilin on visceral endoderm and kidney proximal tubules. Development. 2004; 131:4787-95. [PubMed: 15342463]

28. He Q, Madsen M, Kilkenney A, Gregory B, Christensen EI, et al. Amnionless function is required for cubilin brush-border expression and intrinsic factor-cobalamin (vitamin $\mathrm{B}_{12}$ ) absorption in vivo. Blood. 2005; 106:1447-53. [PubMed: 15845892]

29. Ahuja R, Yammani R, Bauer JA, Kalra S, Seetharam S, Seetharam B. Interactions of cubilin with megalin and the product of the amnionless gene (AMN): effect on its stability. Biochem J. 2008; 410:301-8. [PubMed: 17990981]

30. Anderson CL, Chaudhury C, Kim J, Bronson CL, Wani MA, Mohanty S. Perspective-FcRn transports albumin: relevance to immunology and medicine. Trends Immunol. 2006; 27:343-48. [PubMed: 16731041]

31. Chaudhury C, Mehnaz S, Robinson JM, Hayton WL, Pearl DK, et al. The major histocompatibility complex-related Fc receptor for IgG (FcRn) binds albumin and prolongs its lifespan. J Exp Med. 2003; 197:315-22. [PubMed: 12566415]

32. Akilesh S, Huber TB, Wu H, Wang G, Hartleben B, et al. Podocytes use FcRn to clear IgG from the glomerular basement membrane. PNAS. 2008; 105:967-72. [PubMed: 18198272]

33. Tenten V, Menzel S, Kunter U, Sicking EM, van Roeyen CR, et al. Albumin is recycled from the primary urine by tubular transcytosis. J Am Soc Nephrol. 2013; 24:1966-80. [PubMed: 23970123]

34. Gekle M. Renal albumin handling: a look at the dark side of the filter. Kidney Int. 2007; 71:47981. [PubMed: 17344895]

35. Park $\mathrm{CH}$, Maack T. Albumin absorption and catabolism by isolated perfused proximal convoluted tubules of the rabbit. J Clin Investig. 1984; 73:767-77. [PubMed: 6707203]

36. Gudehithlu KP, Pegoraro AA, Dunea G, Arruda JA, Singh AK. Degradation of albumin by the renal proximal tubule cells and the subsequent fate of its fragments. Kidney Int. 2004; 65:2113-22. [PubMed: 15149324]

37. Hatae T, Fujita M, Sagara H, Okuyama K. Formation of apical tubules from large endocytic vacuoles in kidney proximal tubule cells during absorption of horseradish peroxidase. Cell Tissue Res. 1986; 246:271-78. [PubMed: 3779809]

38. Rabito CA. Phosphate uptake by a kidney cell line (LLC-PK1). Am J Physiol. 1983; 245:F22-31. [PubMed: 6869535]

39. Ryan MJ, Johnson G, Kirk J, Fuerstenberg SM, Zager RA, Torok-Storb B. HK-2: An immortalized proximal tubule epithelial cell line from normal adult human kidney. Kidney Int. 1994; 45:48-57. [PubMed: 8127021] 
40. Mattila PE, Raghavan V, Rbaibi Y, Baty CJ, Weisz OA. Rab11a-positive compartments in proximal tubule cells sort fluid phase and membrane cargo. Am J Physiol Cell Physiol. 2013; 306:C441-49. [PubMed: 24153428]

41. Shmuel M, Nodel-Berner E, Hyman T, Rouvinski A, Altschuler Y. Caveolin 2 regulates endocytosis and trafficking of the M1 muscarinic receptor in MDCK epithelial cells. Mol Biol Cell. 2007; 18:1570-85. [PubMed: 17314410]

42. Zhuang Z, Marshansky V, Breton S, Brown D. Is caveolin involved in normal proximal tubule function? Presence in model PT systems but absence in situ. Am J Physiol Renal Physiol. 2011; 300:F199-206. [PubMed: 20980408]

43. da Costa SR, Okamoto CT, Hamm-Alvarez SF. Actin microfilaments et al.- the many components, effectors and regulators of epithelial cell endocytosis. Adv Drug Deliv Rev. 2003; 55:1359-83. [PubMed: 14597136]

44. Grant BD, Donaldson JG. Pathways and mechanisms of endocytic recycling. Nat Rev Mol Cell Biol. 2009; 10:597-608. [PubMed: 19696797]

45. Huotari J, Helenius A. Endosome maturation. EMBO J. 2011; 30:3481-500. [PubMed: 21878991]

46. Sheff DR, Daro EA, Hull M, Mellman I. The receptor recycling pathway contains two distinct populations of early endosomes with different sorting functions. J Cell Biol. 1999; 145:123-39. [PubMed: 10189373]

47. Wang E, Brown PS, Aroeti B, Chapin SJ, Mostov KE, Dunn KW. Apical and basolateral endocytic pathways of MDCK cells meet in acidic common endosomes distinct from a nearly-neutral apical recycling endosome. Traffic. 2000; 1:480-93. [PubMed: 11208134]

48. Cramm-Behrens CI, Dienst M, Jacob R. Apical cargo traverses endosomal compartments on the passage to the cell surface. Traffic. 2008; 9:2206-20. [PubMed: 18785995]

49. Ang AL, Folsch H, Koivisto UM, Pypaert M, Mellman I. The Rab8 GTPase selectively regulates AP-1B-dependent basolateral transport in polarized Madin-Darby canine kidney cells. J Cell Biol. 2003; 163:339-50. [PubMed: 14581456]

50. Ang AL, Taguchi T, Francis S, Fölsch H, Murrells LJ, et al. Recycling endosomes can serve as intermediates during transport from the Golgi to the plasma membrane of MDCK cells. J Cell Biol. 2004; 167:531-43. [PubMed: 15534004]

51. Sato T, Mushiake S, Kato Y, Sato K, Sato M, et al. The Rab8 GTPase regulates apical protein localization in intestinal cells. Nature. 2007; 448:366-69. [PubMed: 17597763]

52. Huber LA, Pimplikar S, Parton RG, Virta H, Zerial M, Simons K. Rab8, a small GTPase involved in vesicular traffic between the TGN and the basolateral plasma membrane. J Cell Biol. 1993; 123:35-45. [PubMed: 8408203]

53. Knodler A, Feng S, Zhang J, Zhang X, Das A, et al. Coordination of Rab8 and Rab11 in primary ciliogenesis. PNAS. 2010; 107:6346-51. [PubMed: 20308558]

54. Kitt KN, Hernandez-Deviez D, Ballantyne SD, Spiliotis ET, Casanova JE, Wilson JM. Rab14 regulates apical targeting in polarized epithelial cells. Traffic. 2008; 9:1218-31. [PubMed: 18429929]

55. McCarter SD, Johnson DL, Kitt KN, Donohue C, Adams A, Wilson JM. Regulation of tight junction assembly and epithelial polarity by a resident protein of apical endosomes. Traffic. 2010; 11:856-66. [PubMed: 20214753]

56. Su H, Liu B, Frohlich O, Ma H, Sands JM, Chen G. Small GTPase Rab14 down-regulates UT-A1 urea transport activity through enhanced clathrin-dependent endocytosis. FASEB J. 2013; 27:4100-7. [PubMed: 23796783]

57. Rodman JS, Seidman L, Farquhar MG. The membrane composition of coated pits, microvilli, endosomes, and lysosomes is distinctive in the rat kidney proximal tubule cell. J Cell Biol. 1986; 102:77-87. [PubMed: 2867100]

58. Nielsen S. Endocytosis in proximal tubule cells involves a two-phase membrane-recycling pathway. Am J Physiol. 1993; 264:C823-35. [PubMed: 8476017]

59. Rodman JS, Kerjaschki D, Merisko E, Farquhar MG. Presence of an extensive clathrin coat on the apical plasmalemma of the rat kidney proximal tubule cell. J Cell Biol. 1984; 98:1630-36. [PubMed: 6373781] 
60. Birn H, Christensen EI, Nielsen S. Kinetics of endocytosis in renal proximal tubule studied with ruthenium red as membrane marker. Am J Physiol. 1993; 264:F239-50. [PubMed: 7680532]

61. Gekle M, Mildenberger S, Freudinger R, Schwerdt G, Silbernagl S. Albumin endocytosis in OK cells: dependence on actin and microtubules and regulation by protein kinases. Am J Physiol. 1997; 272:F668-77. [PubMed: 9176379]

62. Zhai XY, Nielsen R, Birn H, Drumm K, Mildenberger S, et al. Cubilin- and megalin-mediated uptake of albumin in cultured proximal tubule cells of opossum kidney. Kidney Int. 2000; 58:1523-33. [PubMed: 11012887]

63. Raghavan V, Rbaibi Y, Pastor-Soler NM, Carattino MD, Weisz OA. Shear stress-dependent regulation of apical endocytosis in renal proximal tubule cells mediated by primary cilia. PNAS. 2014; 111:8506-11. [PubMed: 24912170]

64. Decorti G, Malusa N, Furlan G, Candussio L, Klugmann FB. Endocytosis of gentamicin in a proximal tubular renal cell line. Life Sci. 1999; 65:1115-24. [PubMed: 10503927]

65. Lui EC, Bendayan R. Gentamicin uptake by LLCPK1 cells: effect of intracellular and extracellular pH changes. Can J Physiol Pharmacol. 1998; 76:155-60. [PubMed: 9635154]

66. Oleinikov AV, Zhao J, Makker SP. Cytosolic adaptor protein Dab2 is an intracellular ligand of endocytic receptor gp600/megalin. Biochem J. 2000; 347(Pt. 3):613-21. [PubMed: 10769163]

67. Pedersen GA, Chakraborty S, Steinhauser AL, Traub LM, Madsen M. AMN directs endocytosis of the intrinsic factor-vitamin B(12) receptor cubam by engaging ARH or Dab2. Traffic. 2010; 11:706-20. [PubMed: 20088845]

68. Wilund KR, Yi M, Campagna F, Arca M, Zuliani G, et al. Molecular mechanisms of autosomal recessive hypercholesterolemia. Hum Mol Genet. 2002; 11:3019-30. [PubMed: 12417523]

69. Fang L, Garuti R, Kim BY, Wade JB, Welling PA. The ARH adaptor protein regulates endocytosis of the ROMK potassium secretory channel in mouse kidney. J Clin Investig. 2009; 119:3278-89. [PubMed: 19841541]

70. Hatae T, Ichimura T, Ishida T, Sakurai T. Apical tubular network in the rat kidney proximal tubule cells studied by thick-section and scanning electron microscopy. Cell Tissue Res. 1997; 288:31725. [PubMed: 9082967]

71. Nagai M, Meerloo T, Takeda T, Farquhar MG. The adaptor protein ARH escorts megalin to and through endosomes. Mol Biol Cell. 2003; 14:4984-96. [PubMed: 14528014]

72. Anzenberger U, Bit-Avragim N, Rohr S, Rudolph F, Dehmel B, et al. Elucidation of megalin/ LRP2-dependent endocytic transport processes in the larval zebrafish pronephros. J Cell Sci. 2006; 119:2127-37. [PubMed: 16638803]

73. Hurtado-Lorenzo A, Skinner M, El Annan J, Futai M, Sun-Wada GH, et al. V-ATPase interacts with ARNO and Arf6 in early endosomes and regulates the protein degradative pathway. Nat Cell Biol. 2006; 8:124-36. [PubMed: 16415858]

74. Gekle M, Volker K, Mildenberger S, Freudinger R, Shull GE, Wiemann M. NHE3 Na ${ }^{+} / \mathrm{H}^{+}$ exchanger supports proximal tubular protein reabsorption in vivo. Am J Physiol Renal Physiol. 2004; 287:F469-73. [PubMed: 15113744]

75. Scheel O, Zdebik AA, Lourdel S, Jentsch TJ. Voltage-dependent electrogenic chloride/proton exchange by endosomal CLC proteins. Nature. 2005; 436:424-27. [PubMed: 16034422]

76. Schmidt MM, Townson SA, Andreucci AJ, King BM, Schirmer EB, et al. Crystal structure of an HSA/FcRn complex reveals recycling by competitive mimicry of HSA ligands at a $\mathrm{pH}$-dependent hydrophobic interface. Structure. 2013; 21:1966-78. [PubMed: 24120761]

77. Rangel-Filho A, Lazar J, Moreno C, Geurts A, Jacob HJ. Rab38 modulates proteinuria in model of hypertension-associated renal disease. J Am Soc Nephrol. 2013; 24:283-92. [PubMed: 23291471]

78. Schwegler JS, Heppelmann B, Mildenberger S, Silbernagl S. Receptor-mediated endocytosis of albumin in cultured opossum kidney cells: a model for proximal tubular protein reabsorption. Pflugers Arch. 1991; 418:383-92. [PubMed: 1652125]

79. Gotoh N, Yan Q, Du Z, Biemesderfer D, Kashgarian M, et al. Altered renal proximal tubular endocytosis and histology in mice lacking myosin-VI. Cytoskeleton. 2010; 67:178-92. [PubMed: 20175219] 
80. Hosaka K, Takeda T, Iino N, Hosojima M, Sato H, et al. Megalin and nonmuscle myosin heavy chain IIA interact with the adaptor protein Disabled-2 in proximal tubule cells. Kidney Int. 2009; 75:1308-15. [PubMed: 19340093]

81. Thelen S, Abouhamed M, Ciarimboli G, Edemir B, Bahler M. Rho GAP myosin IXa is a regulator of kidney tubule function. Am J Physiol Renal Physiol. 2015; 309:F501-13. [PubMed: 26136556]

82. Dance AL, Miller M, Seragaki S, Aryal P, White B, et al. Regulation of myosin-VI targeting to endocytic compartments. Traffic. 2004; 5:798-813. [PubMed: 15355515]

83. Elkjaer ML, Birn H, Agre P, Christensen EI, Nielsen S. Effects of microtubule disruption on endocytosis, membrane recycling and polarized distribution of Aquaporin-1 and gp330 in proximal tubule cells. Eur J Cell Biol. 1995; 67:57-72. [PubMed: 7543847]

84. Reed AA, Loh NY, Terryn S, Lippiat JD, Partridge C, et al. CLC-5 and KIF3B interact to facilitate CLC-5 plasma membrane expression, endocytosis, and microtubular transport: relevance to pathophysiology of Dent's disease. Am J Physiol Renal Physiol. 2010; 298:F365-80. [PubMed: 19940036]

85. Hryciw DH, Wang Y, Devuyst O, Pollock CA, Poronnik P, Guggino WB. Cofilin interacts with ClC-5 and regulates albumin uptake in proximal tubule cell lines. J Biol Chem. 2003; 278:4016976. [PubMed: 12904289]

86. Dachy A, Paquot F, Debray G, Bovy C, Christensen EI, et al. In-depth phenotyping of a DonnaiBarrow patient helps clarify proximal tubule dysfunction. Pediatr Nephrol. 2015; 30:1027-31. [PubMed: 25822460]

87. Kur E, Christa A, Veth KN, Gajera CR, Andrade-Navarro MA, et al. Loss of Lrp2 in zebrafish disrupts pronephric tubular clearance but not forebrain development. Dev Dyn. 2011; 240:156777. [PubMed: 21455927]

88. Christensen EI, Devuyst O, Dom G, Nielsen R, Van der Smissen P, et al. Loss of chloride channel ClC-5 impairs endocytosis by defective trafficking of megalin and cubilin in kidney proximal tubules. PNAS. 2003; 100:8472-77. [PubMed: 12815097]

89. Moulin P, Igarashi T, Van der Smissen P, Cosyns JP, Verroust P, et al. Altered polarity and expression of $\mathrm{H}^{+}$-ATPase without ultrastructural changes in kidneys of Dent's disease patients. Kidney Int. 2003; 63:1285-95. [PubMed: 12631345]

90. Wang SS, Devuyst O, Courtoy PJ, Wang XT, Wang H, et al. Mice lacking renal chloride channel, CLC-5, are a model for Dent's disease, a nephrolithiasis disorder associated with defective receptor-mediated endocytosis. Hum Mol Genet. 2000; 9:2937-45. [PubMed: 11115837]

91. Chou SY, Hsu KS, Otsu W, Hsu YC, Luo YC, et al. CLIC4 regulates apical exocytosis and renal tube luminogenesis through retromer- and actin-mediated endocytic trafficking. Nat Commun. 2016; 7:10412. [PubMed: 26786190]

92. Morris SM, Tallquist MD, Rock CO, Cooper JA. Dual roles for the Dab2 adaptor protein in embryonic development and kidney transport. EMBO J. 2002; 21:1555-64. [PubMed: 11927540]

93. Nagai J, Christensen EI, Morris SM, Willnow TE, Cooper JA, Nielsen R. Mutually dependent localization of megalin and Dab2 in the renal proximal tubule. Am J Physiol Renal Physiol. 2005; 289:F569-76. [PubMed: 15870384]

94. Koral K, Li H, Ganesh N, Birnbaum MJ, Hallows KR, Erkan E. Akt recruits Dab2 to albumin endocytosis in the proximal tubule. Am J Physiol Renal Physiol. 2014; 307:F1380-89. [PubMed: 25253241]

95. Koral K, Erkan E. PKB/Akt partners with Dab2 in albumin endocytosis. Am J Physiol Renal Physiol. 2012; 302:F1013-24. [PubMed: 22218591]

96. Caruso-Neves C, Kwon SH, Guggino WB. Albumin endocytosis in proximal tubule cells is modulated by angiotensin II through an $\mathrm{AT}_{2}$ receptor-mediated protein kinase $\mathrm{B}$ activation. PNAS. 2005; 102:17513-18. [PubMed: 16293694]

97. Carpentier S, N'Kuli F, Grieco G, Van Der Smissen P, Janssens V, et al. Class III phosphoinositide 3-kinase/VPS34 and dynamin are critical for apical endocytic recycling. Traffic. 2013; 14:933-48. [PubMed: 23621784]

98. Brunskill NJ, Stuart J, Tobin AB, Walls J, Nahorski S. Receptor-mediated endocytosis of albumin by kidney proximal tubule cells is regulated by phosphatidylinositide 3-kinase. J Clin Investig. 1998; 101:2140-50. [PubMed: 9593770] 
99. Hosojima M, Sato H, Yamamoto K, Kaseda R, Soma T, et al. Regulation of megalin expression in cultured proximal tubule cells by angiotensin II type 1A receptor- and insulin-mediated signaling cross talk. Endocrinology. 2009; 150:871-78. [PubMed: 18927221]

100. Takeyama A, Sato H, Soma-Nagae T, Kabasawa H, Suzuki A, et al. Megalin is downregulated via LPS-TNF-a-ERK1/2 signaling pathway in proximal tubule cells. Biochem Biophys Res Commun. 2011; 407:108-12. [PubMed: 21371423]

101. Ruggiero C, Elks CM, Kruger C, Cleland E, Addison K, et al. Albumin-bound fatty acids but not albumin itself alter redox balance in tubular epithelial cells and induce a peroxide-mediated redox-sensitive apoptosis. Am J Physiol Renal Physiol. 2014; 306:F896-906. [PubMed: 24500687]

102. Caruso-Neves C, Pinheiro AA, Cai H, Souza-Menezes J, Guggino WB. PKB and megalin determine the survival or death of renal proximal tubule cells. PNAS. 2006; 103:18810-15. [PubMed: 17121993]

103. Gekle M, Mildenberger S, Freudinger R, Silbernagl S. Long-term protein exposure reduces albumin binding and uptake in proximal tubule-derived opossum kidney cells. J Am Soc Nephrol. 1998; 9:960-68. [PubMed: 9621278]

104. Diwakar R, Pearson AL, Colville-Nash P, Baines DL, Dockrell ME. Role played by Disabled-2 in albumin induced MAP Kinase signalling. Biochem Biophys Res Commun. 2008; 366:675-80. [PubMed: 18070591]

105. Slattery C, Jang Y, Kruger WA, Hryciw DH, Lee A, Poronnik P. $\gamma$-Secretase inhibition promotes fibrotic effects of albumin in proximal tubular epithelial cells. Br J Pharmacol. 2013; 169:123951. [PubMed: 23594166]

106. Gekle M, Knaus P, Nielsen R, Mildenberger S, Freudinger R, et al. Transforming growth factorbeta1 reduces megalin- and cubilin-mediated endocytosis of albumin in proximal-tubule-derived opossum kidney cells. J Physiol. 2003; 552:471-81. [PubMed: 14561830]

107. Slattery C, Jenkin KA, Lee A, Simcocks AC, McAinch AJ, et al. $\mathrm{Na}^{+}-\mathrm{H}^{+}$exchanger regulatory factor 1 (NHERF1) PDZ scaffold binds an internal binding site in the scavenger receptor megalin. Cell Physiol Biochem. 2011; 27:171-78. [PubMed: 21325834]

108. Hryciw DH, Jenkin KA, Simcocks AC, Grinfeld E, McAinch AJ, Poronnik P. The interaction between megalin and $\mathrm{ClC}-5$ is scaffolded by the $\mathrm{Na}^{+}-\mathrm{H}^{+}$exchanger regulatory factor 2 (NHERF2) in proximal tubule cells. Int J Biochem Cell Biol. 2012; 44:815-23. [PubMed: 22349218]

109. Biemesderfer D, Nagy T, DeGray B, Aronson PS. Specific association of megalin and the $\mathrm{Na}^{+} / \mathrm{H}^{+}$ exchanger isoform NHE3 in the proximal tubule. J Biol Chem. 1999; 274:17518-24. [PubMed: 10364184]

110. Lee A, Slattery C, Nikolic-Paterson DJ, Hryciw DH, Wilk S, et al. Chloride channel ClC-5 binds to aspartyl aminopeptidase to regulate renal albumin endocytosis. Am J Physiol Renal Physiol. 2015; 308:F784-92. [PubMed: 25587118]

111. Hryciw DH, Ekberg J, Lee A, Lensink IL, Kumar S, et al. Nedd4-2 functionally interacts with ClC-5: involvement in constitutive albumin endocytosis in proximal tubule cells. J Biol Chem. 2004; 279:54996-5007. [PubMed: 15489223]

112. Dobrinskikh E, Lewis L, Brian Doctor R, Okamura K, Lee MG, et al. Shank2 regulates renal albumin endocytosis. Physiol Rep. 2015; 3:e12510. [PubMed: 26333830]

113. Ferrell N, Ricci KB, Groszek J, Marmerstein JT, Fissell WH. Albumin handling by renal tubular epithelial cells in a microfluidic bioreactor. Biotechnol Bioeng. 2012; 109:797-803. [PubMed: 22012446]

114. Schnatwinkel C, Christoforidis S, Lindsay MR, Uttenweiler-Joseph S, Wilm M, et al. The Rab5 effector Rabankyrin-5 regulates and coordinates different endocytic mechanisms. PLOS Biol. 2004; 2:E261. [PubMed: 15328530]

115. Pohl M, Shan Q, Petsch T, Styp-Rekowska B, Matthey P, et al. Short-term functional adaptation of aquaporin-1 surface expression in the proximal tubule, a component of glomerulotubular balance. J Am Soc Nephrol. 2015; 26:1269-78. [PubMed: 25270072] 
116. Kolb RJ, Woost PG, Hopfer U. Membrane trafficking of angiotensin receptor type-1 and mechanochemical signal transduction in proximal tubule cells. Hypertension. 2004; 44:352-59. [PubMed: 15262908]

117. Duan Y, Weinstein AM, Weinbaum S, Wang T. Shear stress-induced changes of membrane transporter localization and expression in mouse proximal tubule cells. PNAS. 2010; 107:21860 65. [PubMed: 21106755]

118. Nielsen R, Christensen EI, Birn H. Megalin and cubilin in proximal tubule protein reabsorption: from experimental models to human disease. Kidney Int. 2016; 89:58-67. [PubMed: 26759048]

119. Wilmer MJ, Emma F, Levtchenko EN. The pathogenesis of cystinosis: mechanisms beyond cystine accumulation. Am J Physiol Renal Physiol. 2010; 299:F905-16. [PubMed: 20826575]

120. Sansanwal P, Yen B, Gahl WA, Ma Y, Ying L, et al. Mitochondrial autophagy promotes cellular injury in nephropathic cystinosis. J Am Soc Nephrol. 2010; 21:272-83. [PubMed: 19959713]

121. Napolitano G, Johnson JL, He J, Rocca CJ, Monfregola J, et al. Impairment of chaperonemediated autophagy leads to selective lysosomal degradation defects in the lysosomal storage disease cystinosis. EMBO Mol Med. 2015; 7:158-74. [PubMed: 25586965]

122. Gaide Chevronnay HP, Janssens V, Van Der Smissen P, N'Kuli F, Nevo N, et al. Time course of pathogenic and adaptation mechanisms in cystinotic mouse kidneys. J Am Soc Nephrol. 2014; 25:1256-69. [PubMed: 24525030]

123. Wilmer MJ, Christensen EI, van den Heuvel LP, Monnens LA, Levtchenko EN. Urinary protein excretion pattern and renal expression of megalin and cubilin in nephropathic cystinosis. Am $\mathrm{J}$ Kidney Dis. 2008; 51:893-903. [PubMed: 18455850]

124. Johnson JL, Napolitano G, Monfregola J, Rocca CJ, Cherqui S, Catz SD. Upregulation of the Rab27a-dependent trafficking and secretory mechanisms improves lysosomal transport, alleviates endoplasmic reticulum stress, and reduces lysosome overload in cystinosis. Mol Cell Biol. 2013; 33:2950-62. [PubMed: 23716592]

125. Devuyst O, Thakker RV. Dent's disease. Orphanet J Rare Dis. 2010; 5:28. [PubMed: 20946626]

126. Günther W, Lüchow A, Cluzeaud F, Vandewalle A, Jentsch TJ. ClC-5, the chloride channel mutated in Dent's disease, colocalizes with the proton pump in endocytotically active kidney cells. PNAS. 1998; 95:8075-80. [PubMed: 9653142]

127. Piwon N, Günther W, Schwake M, Bösl MR, Jentsch TJ. ClC-5 $\mathrm{Cl}^{-}$-channel disruption impairs endocytosis in a mouse model for Dent's disease. Nature. 2000; 408:369-73. [PubMed: 11099045]

128. Maritzen T, Lisi S, Botta R, Pinchera A, Fanelli G, et al. ClC-5 does not affect megalin expression and function in the thyroid. Thyroid. 2006; 16:725-30. [PubMed: 16910872]

129. Gorvin CM, Wilmer MJ, Piret SE, Harding B, van den Heuvel LP, et al. Receptor-mediated endocytosis and endosomal acidification is impaired in proximal tubule epithelial cells of Dent disease patients. PNAS. 2013; 110:7014-19. [PubMed: 23572577]

130. Novarino G, Weinert S, Rickheit G, Jentsch TJ. Endosomal chloride-proton exchange rather than chloride conductance is crucial for renal endocytosis. Science. 2010; 328:1398-401. [PubMed: 20430975]

131. Rickheit G, Wartosch L, Schaffer S, Stobrawa SM, Novarino G, et al. Role of ClC-5 in renal endocytosis is unique among $\mathrm{ClC}$ exchangers and does not require PY-motif-dependent ubiquitylation. J Biol Chem. 2010; 285:17595-603. [PubMed: 20351103]

132. Schwake M, Friedrich T, Jentsch TJ. An internalization signal in ClC-5, an endosomal $\mathrm{Cl}^{-}$ channel mutated in Dent's disease. J Biol Chem. 2001; 276:12049-54. [PubMed: 11116157]

133. Bokenkamp A, Ludwig M. The oculocerebrorenal syndrome of Lowe: an update. Pediatr Nephrol. 2016; In press. doi: 10.1007/s00467-016-3343-3

134. Dressman MA, Olivos-Glander IM, Nussbaum RL, Suchy SF. Ocrl1, a PtdIns(4,5)P(2) 5phosphatase, is localized to the trans-Golgi network of fibroblasts and epithelial cells. J Histochem Cytochem. 2000; 48:179-90. [PubMed: 10639484]

135. Mehta ZB, Pietka G, Lowe M. The cellular and physiological functions of the Lowe syndrome protein OCRL1. Traffic. 2014; 15:471-87. [PubMed: 24499450] 
136. Janne PA, Suchy SF, Bernard D, MacDonald M, Crawley J, et al. Functional overlap between murine Inpp5b and Ocrl1 may explain why deficiency of the murine ortholog for OCRL1 does not cause Lowe syndrome in mice. J Clin Investig. 1998; 101:2042-53. [PubMed: 9593760]

137. Bothwell SP, Chan E, Bernardini IM, Kuo YM, Gahl WA, Nussbaum RL. Mouse model for Lowe syndrome/Dent Disease 2 renal tubulopathy. J Am Soc Nephrol. 2011; 22:443-48. [PubMed: 21183592]

138. Zhang X, Jefferson AB, Auethavekiat V, Majerus PW. The protein deficient in Lowe syndrome is a phosphatidylinositol-4,5-bisphosphate 5-phosphatase. PNAS. 1995; 92:4853-56. [PubMed: 7761412]

139. Guerriero CJ, Weixel KM, Bruns JR, Weisz OA. Phosphatidylinositol 5-kinase stimulates apical biosynthetic delivery via an Arp2/3-dependent mechanism. J Biol Chem. 2006; 281:15376-84. [PubMed: 16601114]

140. Allen PG. Actin filament uncapping localizes to ruffling lamellae and rocketing vesicles. Nat Cell Biol. 2003; 5:972-79. [PubMed: 14557819]

141. Ungewickell AJ, Majerus PW. Increased levels of plasma lysosomal enzymes in patients with Lowe syndrome. PNAS. 1999; 96:13342-44. [PubMed: 10557322]

142. Choudhury R, Diao A, Zhang F, Eisenberg E, Saint-Pol A, et al. Lowe syndrome protein OCRL1 interacts with clathrin and regulates protein trafficking between endosomes and the trans-Golgi network. Mol Biol Cell. 2005; 16:3467-79. [PubMed: 15917292]

143. Cui S, Guerriero CJ, Szalinski CM, Kinlough CL, Hughey RP, Weisz OA. OCRL1 function in renal epithelial membrane traffic. Am J Physiol Renal Physiol. 2010; 298:F335-45. [PubMed: 19940034]

144. Nielsen R, Courtoy PJ, Jacobsen C, Dom G, Lima WR, et al. Endocytosis provides a major alternative pathway for lysosomal biogenesis in kidney proximal tubular cells. PNAS. 2007; 104:5407-12. [PubMed: 17369355]

145. Nandez R, Balkin DM, Messa M, Liang L, Paradise S, et al. A role of OCRL in clathrin-coated pit dynamics and uncoating revealed by studies of Lowe syndrome cells. eLife. 2014; 3:e02975. [PubMed: 25107275]

146. Noakes CJ, Lee G, Lowe M. The PH domain proteins IPIP27A and B link OCRL1 to receptor recycling in the endocytic pathway. Mol Biol Cell. 2011; 22:606-23. [PubMed: 21233288]

147. Vicinanza M, Di Campli A, Polishchuk E, Santoro M, Di Tullio G, et al. OCRL controls trafficking through early endosomes via PtdIns4,5P(2)-dependent regulation of endosomal actin. EMBO J. 2011; 30:4970-85. [PubMed: 21971085]

148. Oltrabella F, Pietka G, Ramirez IB, Mironov A, Starborg T, et al. The Lowe syndrome protein OCRL1 is required for endocytosis in the zebrafish pronephric tubule. PLOS Genet. 2015; 11:e1005058. [PubMed: 25838181]

149. Dambournet D, Machicoane M, Chesneau L, Sachse M, Rocancourt M, et al. Rab35 GTPase and OCRL phosphatase remodel lipids and F-actin for successful cytokinesis. Nat Cell Biol. 2011; 13:981-88. [PubMed: 21706022] 


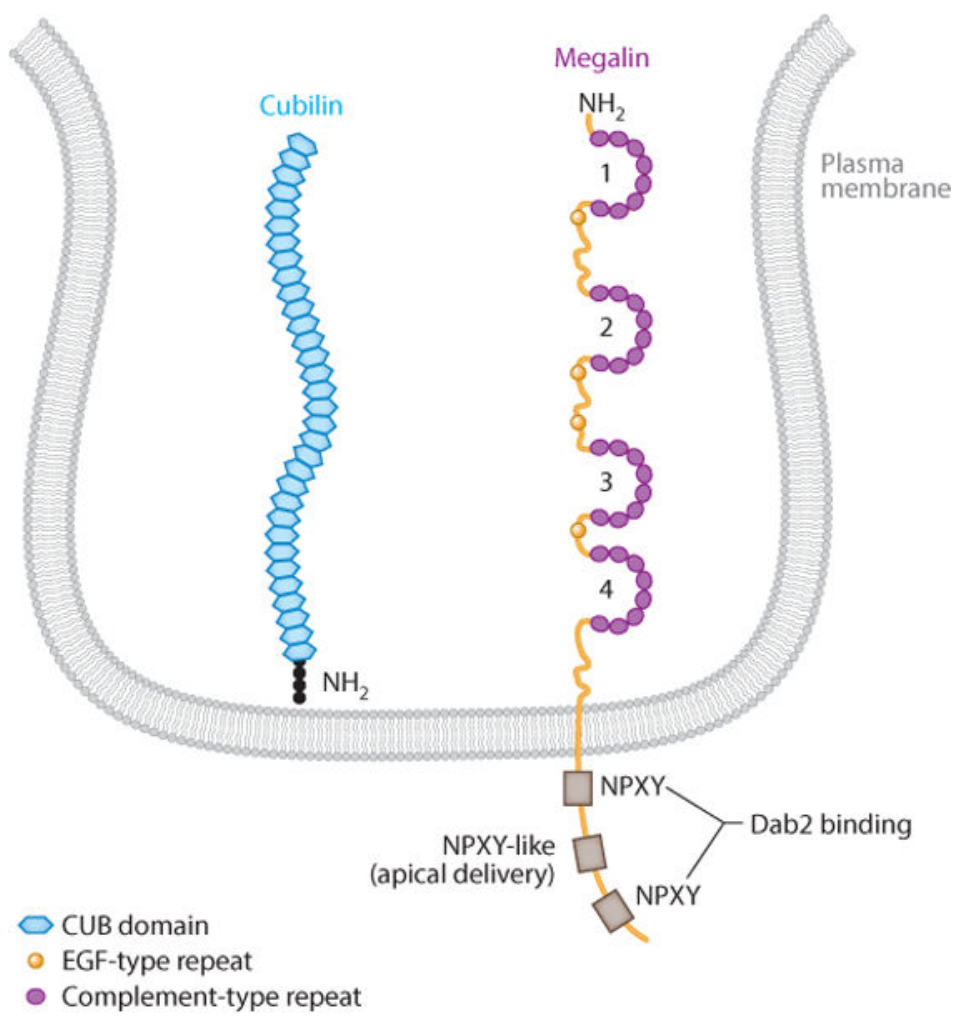

Figure 1.

Multiligand receptors in the proximal tubule. Megalin and cubilin regulate the uptake of low molecular weight proteins from the glomerular filtrate. The cytoplasmic tail of megalin contains two NPXY motifs that bind to the Dab2 clathrin adaptor protein as well as a related NQNY sequence implicated in apical delivery. Megalin/cubilin ligands that are filtered through the glomerular barrier are listed in Table 1. Abbreviations: CUB, compliment C1r/ C1s, Uegf, Bmp1; Dab2, Disabled-2 protein; EGF, epidermal growth factor. 


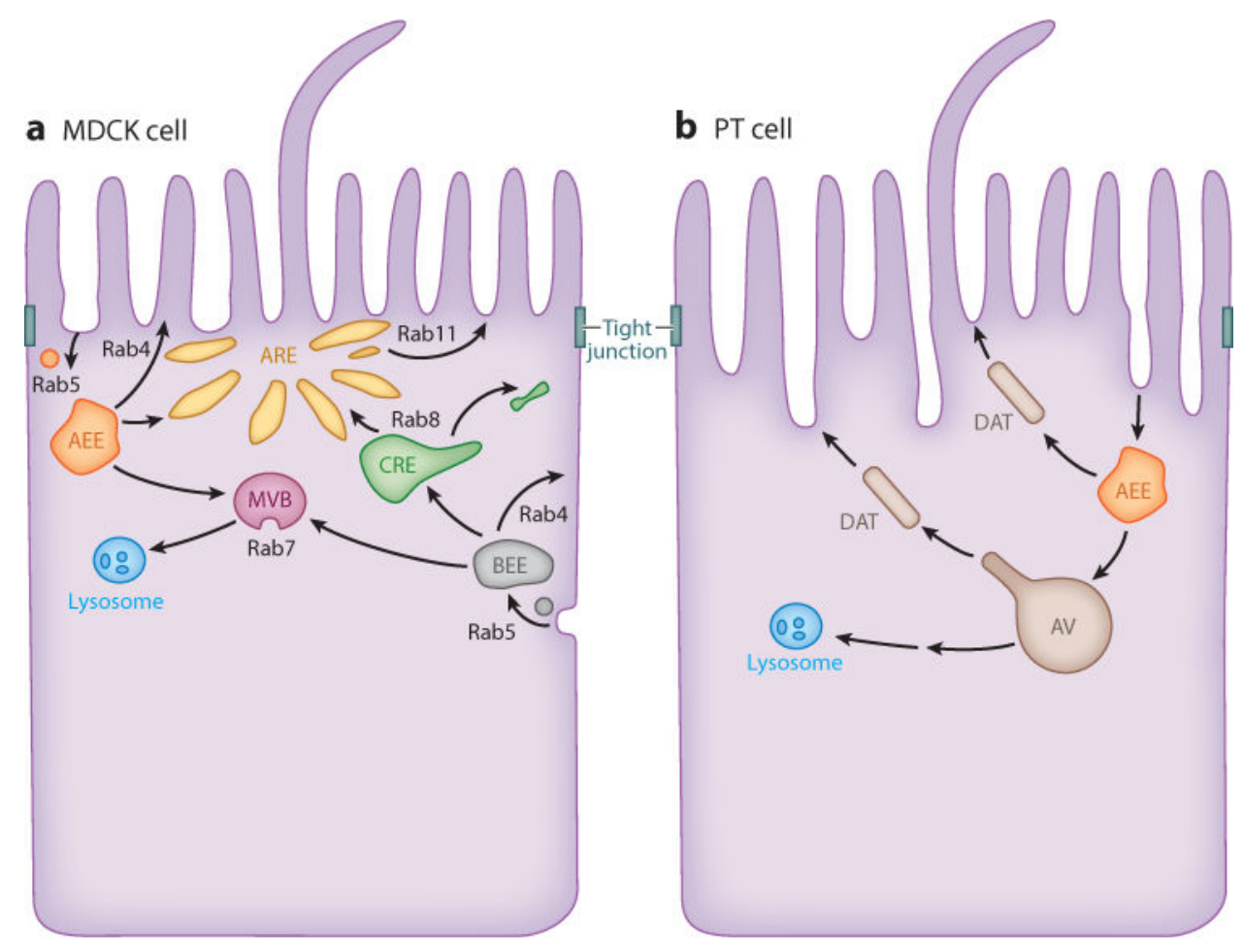

Figure 2.

The apical endocytic pathway in MDCK and PT cells. (a) Cargo internalized from the apical and basolateral surface of MDCK cells via clathrin-coated pits enters Rab5-positive AEEs and BEEs, respectively. Most proteins return to the plasma membrane from these compartments via a Rab4-dependent fast recycling pathway, but they may also be delivered to Rab11-positive AREs or Rab8-positive CREs. Ligands released from internalized receptors in acidified early endosomes are transported to Rab7-positive MVBs and eventually to lysosomes. (b) In PT cells, apical proteins are internalized in irregular clathrincoated invaginations into apical early endosomes that fuse to form larger AVs. Recycling of membrane proteins can occur from AEEs or AVs via DATs, whereas soluble components of AVs are delivered to lysosomes. The Rab proteins and other machinery associated with these compartments remain largely unknown. Abbreviations: AEE, apical early endosomes; ARE, apical recycling endosomes; AV, apical vacuole; BEE, basolateral early endosomes; CRE, common recycling endosomes; DAT, dense apical tubules; MDCK, Madin-Darby canine kidney; MVB, multivesicular bodies; PT, proximal tubule. 
Table 1

Megalin and cubilin ligands that are filtered through the glomerular barrier

\begin{tabular}{|c|c|c|}
\hline Protein & Megalin ligand & Cubilin ligand \\
\hline \multicolumn{3}{|l|}{ Vitamin carrier proteins } \\
\hline Vitamin D-binding protein & Yes & Yes \\
\hline Folate-binding protein & Yes & \\
\hline Retinol-binding protein & Yes & \\
\hline Transcobalamin, Transcobamalin II & Yes & \\
\hline Intrinsic factor & & Yes \\
\hline \multicolumn{3}{|l|}{ Other carrier proteins } \\
\hline Albumin & Yes & Yes \\
\hline Hemoglobin & Yes & Yes \\
\hline Myoglobin & Yes & Yes \\
\hline Lactoferrin & Yes & \\
\hline Liver-type fatty acid-binding protein & Yes & \\
\hline Metallothionein & Yes & \\
\hline Neutrophil gelatinase-associated lipocalin & Yes & \\
\hline Odorant-binding protein & Yes & \\
\hline Selenoprotein P & Yes & \\
\hline Sex hormone-binding globulin & Yes & \\
\hline Transthyretin & Yes & \\
\hline Transferrin & & Yes \\
\hline \multicolumn{3}{|l|}{ Lipoproteins } \\
\hline Apolipoprotein B & Yes & \\
\hline Apolipoprotein E & Yes & \\
\hline Apolipoprotein $\mathrm{J} /$ clusterin & Yes & \\
\hline Apolipoprotein $\mathrm{H}$ & Yes & \\
\hline Apolipoprotein M & Yes & \\
\hline Apolipoprotein A-I & & Yes \\
\hline High-density lipoprotein & & Yes \\
\hline \multicolumn{3}{|l|}{ Hormones and signaling proteins } \\
\hline Angiotensin II & Yes & \\
\hline Bone morphogenic protein 4 & Yes & \\
\hline Connective tissue growth factor & Yes & \\
\hline Epidermal growth factor & Yes & \\
\hline Insulin & Yes & \\
\hline Insulin-like growth factor & Yes & \\
\hline Leptin & Yes & \\
\hline Parathyroid hormone & Yes & \\
\hline Prolactin & Yes & \\
\hline
\end{tabular}




\begin{tabular}{|c|c|c|}
\hline Protein & Megalin ligand & Cubilin ligand \\
\hline Sonic hedgehog protein & Yes & \\
\hline Survivin & Yes & \\
\hline Thyroglobulin & Yes & \\
\hline Fibroblast growth factor & & Yes \\
\hline \multicolumn{3}{|l|}{ Enzymes and enzyme inhibitors } \\
\hline Recombinant activated factor VIIa & Yes & Yes \\
\hline a-amylase & Yes & \\
\hline a-galactosidase $\mathrm{A}$ & Yes & \\
\hline Cathepsin B & Yes & \\
\hline Cystatin C & Yes & \\
\hline Lysozyme & Yes & \\
\hline Plasminogen & Yes & \\
\hline Plasminogen activator inhibitor type I & Yes & \\
\hline Tissue plasminogen activator & Yes & \\
\hline Urokinase & Yes & \\
\hline Lipoprotein lipase & Yes & \\
\hline \multicolumn{3}{|l|}{ Immune- and stress-related proteins } \\
\hline Immunoglobulin light chains & Yes & Yes \\
\hline$a_{1}$-microglobulin & Yes & Yes \\
\hline$\beta_{2}$-microglobulin, Pancreatitis-associated protein & Yes & \\
\hline Clara cell secretory protein & & Yes \\
\hline \multicolumn{3}{|l|}{ Drugs and toxins } \\
\hline Aminoglycosides & Yes & Yes \\
\hline Aprotinin & Yes & \\
\hline Colistin & Yes & \\
\hline Gentamicin & Yes & \\
\hline Polymyxin B & Yes & \\
\hline Trichosanthin & Yes & \\
\hline \multicolumn{3}{|l|}{ Others } \\
\hline $\mathrm{Ca}^{2+}$ & Yes & Yes \\
\hline Receptor-associated protein & Yes & Yes \\
\hline Coagulation factor VII & Yes & Yes \\
\hline Coagulation factor VIII & Yes & \\
\hline Cytochrome C & Yes & \\
\hline Seminal vesicle secretory protein II & Yes & \\
\hline Advanced glycation end products & Yes & \\
\hline
\end{tabular}

